\title{
Silicosis among grindstone cutters in the north of Nigeria
}

\author{
D.A. W A R R E L L, B. D.W . H A R R I S O N, \\ I. W. F A W CET T, Y. MOH A M M D, \\ W. S. MOHAMMED, HELEN M. POPE, a nd \\ B A R B A R A J. W A T K I N S \\ Department of Medicine, Ahmadu Bello University, Zaria, Nigeria
}

\begin{abstract}
Warrell, D. A., Harrison, B. D. W., Fawcett, I. W., Mohammed, Y., Mohammed, W. S., Pope, Helen M., and Watkins, Barbara J. (1975). Thorax, 30, 389-398. Silicosis among grindstone cutters in the north of Nigeria. Many of the grindstones used in Nigerian homes are quarried from sandstone in a small group of villages near Kano in the extreme north of the country. Of an unselected group of 126 stonecutters from two of these villages 49 were found to have radiographic evidence of silicosis, with progressive massive fibrosis in 17.

Those with silicosis had worked longer in the quarries than 77 whose radiographs showed no evidence of silicosis. Sixty-three per cent of the silicotics had respiratory symptoms, the commonest being breathlessness on moderate exertion. Cough was the earliest symptom in $42 \%$. Only $35 \%$ had abnormal physical signs in the cardiorespiratory system, $18 \%$ had clearly reduced ventilatory capacity, and airways obstruction was evident in $16 \%$.

The prevalence of silicosis in these open-cast sandstone quarriers is unexpectedly high. This is probably explained by the intensity of exposure and the particular kind of sandstone being worked.

Reduction of dust exposure in these quarries raises severe practical problems, but the inhabitants of this drought-ridden area can scarcely be expected to abandon their traditional livelihood.
\end{abstract}

Interest in the grindstone quarriers of northern Nigeria was aroused in 1971 when a 25-year-old man (the index case) presented at Ahmadu Bello University (ABU) Hospital, Zaria with severe respiratory symptoms. He had been a stonecutter making grindstones since the age of 5 years; most of the men in his district were similarly employed and many of them had developed respiratory symptoms and died young. His sputum contained acid-fast bacilli and his radiograph showed diffuse nodular opacities, suggesting pneumoconiosis with superimposed appearances of active tuberculosis. An open lung biopsy showed evidence of indolent tuberculosis.

As a result of a preliminary visit to his village in 1972, a survey of this and a neighbouring village was arranged with the approval and cooperation of the Ministry of Health, Kano State and was carried out in the second week of December 1973.

\section{THE OCCUPATION OF STONECUTTING (HAUSA-SARANDUTSE, MAKO'DA)}

The quarries are situated along a sandstone escarpment, one of the southern outliers of the Sahelian cretaceous sedimentary deposit, between the villages of Ganji $\left(8^{\circ} 22^{\prime} \mathrm{E}, 12^{\circ} 22^{\prime} \mathrm{N}\right)$ and Marken Mako'da. $\left(8^{\circ} 22^{\prime} \mathrm{E}, 12^{\circ} 22^{\prime} \mathrm{N}\right) 70 \mathrm{~km}$ northwest of Kano. The traditional dry season occupation in these villages is chipping grindstones out of the rock using a simple steel-headed pick (Fig. 1). The finished grindstone consists of a larger 'mother' stone (Hausa-uwa), $35 \times 52 \times$ $4 \mathrm{~cm}$, and a smaller 'son' stone (Hausa-da), $37 \times 11 \times 4 \mathrm{~cm}$. These are used by housewives all 


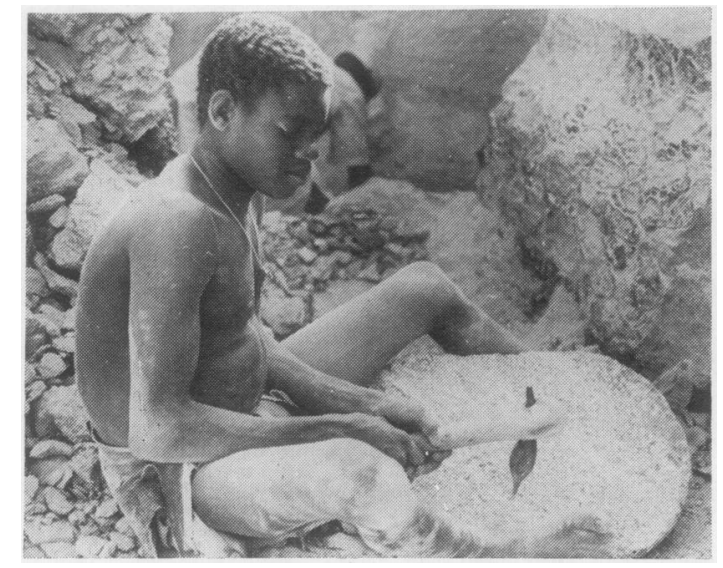

FIG. 1. Stonecutter in Hasiya pit, Marken Mako'da applying the finishing touches to a grindstone while sitting in the dusty bottom of the pit.

over Nigeria and in neighbouring countries for grinding grains and peppers (Fig. 2). Excavating the grindstone involves chipping a groove about $5 \mathrm{~cm}$ deep, a very dusty procedure (Fig. 3), and then cleaving out the stone in the plane of its grain. Trimming the stone and finishing it to give the grinding surface is usually done in the pit where it is dusty but shaded. Some quarries are merely shallow hollows while some have caves, but the commonest plan is a pit, approximately $7 \mathrm{~m}^{2}$ and $4 \mathrm{~m}$ deep.

In recent years the stonecutters have realized that their occupation is unhealthy. They recognize that after 10-15 years' exposure chest pain followed by haemoptysis, breathlessness, and premature death may result.

SUBJECTS One hundred and twenty-six stonecutters volunteered for the study, representing all the stonecutters, active and retired, from Ganji and all but two of those who lived in Marken Mako'da. These two villages are $10 \mathrm{~km}$ west and $18 \mathrm{~km}$ south-west of Dambatta General Hospital, the organizing centre for the survey.

\section{METHODS}

Standard questionnaires covering details of occupational and clinical history were completed by a doctor and senior medical student who speak Kano Hausa as their first language.

A full physical examination of each subject included height and weight and concentrated on signs of cardiorespiratory disease and other types

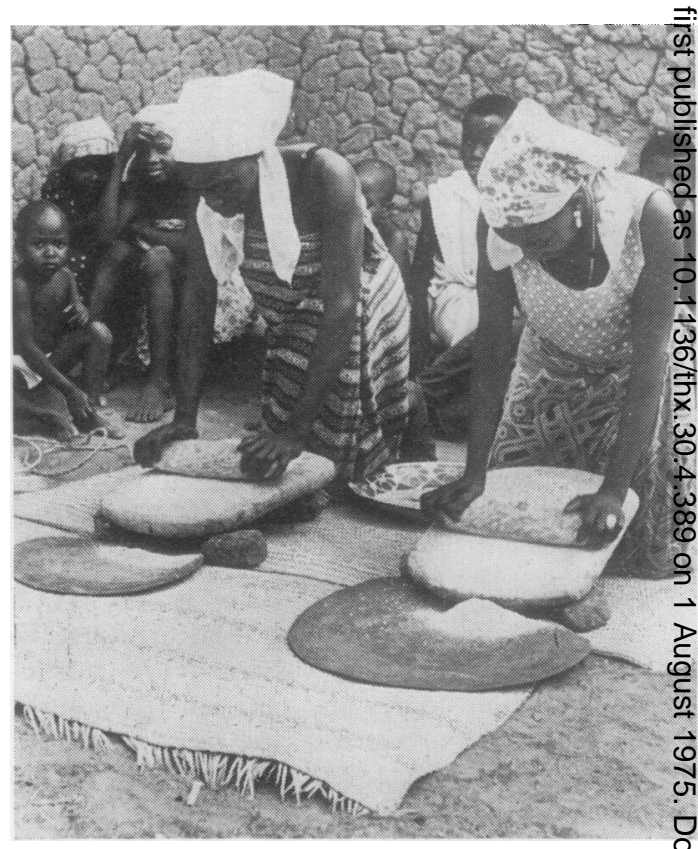

FIG. 2. Grindstones in use. Hausa women grindi guinea corn in Zaria City using stones from Mark Mako'da.

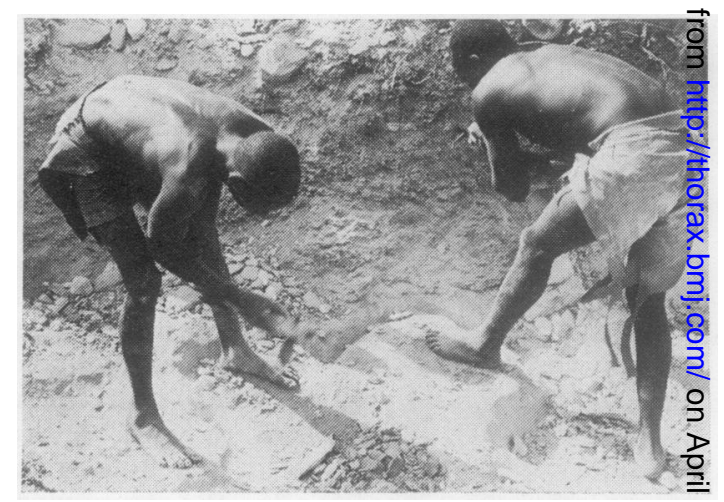

FIG. 3. Chipping grindstones out of the bed rod the dustiest part of the operation.

of occupational lesion resulting from stonecutting, such as hand and eye injuries.

Ventilatory capacity was measured by the forced expired volume in the first second (FEV and forced vital capacity (FVC) using McDermott bellows spirometer which was frequently calibrated. Peak expiratory flow (PER) was measured with a Wright peak flow meter. Tige best of three good efforts was recorded. 
T A B L E I

RADIOGRAPHIC APPEARANCES CLASSIFIED ACCORDING TO THE ILO U/C INTERNATIONAL CLASSIFICATION OF RADIOGRAPHS OF PNEUMOCONIOSIS 1971

\begin{tabular}{|c|c|c|c|c|c|c|c|c|c|c|c|c|c|c|c|c|c|c|c|c|}
\hline \multirow{3}{*}{ Category } & \multirow{3}{*}{$\begin{array}{c}\text { Total } \\
\text { No. }\end{array}$} & & & & \multicolumn{4}{|c|}{ Rounded Small Opacities } & \multicolumn{6}{|c|}{ Irregular Small Opacities } & \multicolumn{6}{|c|}{ Large Opacities } \\
\hline & & \multicolumn{3}{|c|}{ Profusion } & \multicolumn{2}{|c|}{ Type } & \multicolumn{2}{|c|}{ Zones } & \multicolumn{4}{|c|}{ Type } & \multicolumn{2}{|c|}{ Zones } & \multicolumn{2}{|c|}{$\mathbf{A}$} & \multicolumn{2}{|c|}{$\mathbf{B}$} & \multicolumn{2}{|c|}{$\mathbf{C}$} \\
\hline & & & & & $q$ & $\mathbf{r}$ & Mean & Range & s & t & $u$ & 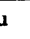 & Mean & Range & wd & id & wd & & wd & \\
\hline \multirow[b]{2}{*}{0} & \multirow[b]{2}{*}{77} & $0 /-$ & $0 / 0$ & $0 / 1$ & \multirow[b]{2}{*}{1} & \multirow[b]{2}{*}{1} & \multirow{2}{*}{\multicolumn{2}{|c|}{2}} & \multirow{2}{*}{\multicolumn{4}{|c|}{1}} & \multirow{2}{*}{\multicolumn{2}{|c|}{1}} & & & & & & \\
\hline & & 0 & 74 & 3 & & & & & & & & & & & & & & & & \\
\hline \multirow[b]{2}{*}{1} & \multirow[b]{2}{*}{6} & $0 / 1$ & $1 / 1$ & $1 / 2$ & \multirow{2}{*}{\multicolumn{2}{|c|}{1}} & \multirow{2}{*}{\multicolumn{2}{|c|}{1}} & \multirow[b]{2}{*}{1} & \multirow{2}{*}{\multicolumn{3}{|c|}{3}} & \multirow[b]{2}{*}{$3 \cdot 3$} & \multirow[b]{2}{*}{$1-5$} & & & & & & \\
\hline & & 1 & 5 & 0 & & & & & & & & & & & & & & & & \\
\hline \multirow[b]{2}{*}{2} & \multirow[b]{2}{*}{31} & $2 / 1$ & $2 / 2$ & $2 / 3$ & \multirow[b]{2}{*}{15} & \multirow[b]{2}{*}{7} & \multirow[b]{2}{*}{$4 \cdot 7$} & & & & & & & & & & & & & \\
\hline & & 4 & 19 & 8 & & & & $1-6$ & & 1 & & 8 & $4 \cdot 3$ & $2-6$ & 4 & 2 & 2 & 2 & 0 & 2 \\
\hline & & $3 / 2$ & $3 / 3$ & $3 / 4$ & & & & & & & & & & & & & & & & \\
\hline 3 & 12 & 5 & 7 & 0 & 1 & 11 & $5 \cdot 5$ & $2-6$ & & & & 2 & $3 \cdot 5$ & $2-5$ & 1 & 0 & 0 & 1 & 1 & 2 \\
\hline Total & 126 & & & & 18 & 19 & & & & 1 & 1 & & & & 5 & 2 & 2 & 3 & 1 & 4 \\
\hline
\end{tabular}

\begin{tabular}{|c|c|c|c|c|c|c|c|c|c|c|c|c|c|c|c|c|c|c|c|c|c|c|c|}
\hline \multirow{3}{*}{ Category } & \multicolumn{7}{|c|}{ Pleural Thickening } & \multirow{2}{*}{\multicolumn{2}{|c|}{$\begin{array}{l}\text { Ill-defined } \\
\text { Diaphragm }\end{array}$}} & \multirow{2}{*}{\multicolumn{3}{|c|}{$\begin{array}{l}\text { Cardiac } \\
\text { Outline }\end{array}$}} & \multirow{2}{*}{\multicolumn{11}{|c|}{ Symbols }} \\
\hline & \multicolumn{2}{|c|}{$\begin{array}{c}\text { Costophrenic } \\
\text { Angle }\end{array}$} & \multicolumn{2}{|c|}{ Site } & \multicolumn{2}{|c|}{ Width } & Extent & & & & & & & & & & & & & & & & \\
\hline & $\mathbf{R}$ & $\mathbf{L}$ & $\mathbf{R}$ & & a & b & 12 & $\mathbf{R}$ & $\mathbf{L}$ & 1 & 2 & 3 & $a x$ & ca & cn & co & cv & $\mathrm{di}$ & es & hi & od & tba & $\overrightarrow{\text { tbu }}$ \\
\hline 0 & & & & & & & & & & & & & & 1 & & & & & & 3 & & & \\
\hline 1 & & & & & & & & 1 & & & & & & & & & & & 1 & 2 & 1 & & \\
\hline 2 & 1 & 5 & 4 & 7 & 3 & 4 & 25 & 3 & 3 & 0 & 2 & 1 & 9 & & 1 & 4 & 3 & 4 & & & & 4 & 2 \\
\hline 3 & 1 & 3 & 3 & 1 & 3 & 0 & 21 & 3 & 3 & 2 & 1 & 2 & 10 & & 1 & & & 1 & & 1 & & & 1 \\
\hline Total & & & & & & & & & & & & & 19 & 1 & 2 & 4 & 3 & 5 & 1 & 6 & 1 & 4 & 3 \\
\hline
\end{tabular}


A single fresh sputum sample from each subject was stained by Ziehl-Neelsen's method and examined for ten minutes for acid-fast bacilli.

Venous blood was sampled for measurement of haematocrit and rheumatoid factor (Greenwood, Muller, and Valkenburg, 1971).

Postero-anterior chest radiographs were taken in the ABU Orthopaedic Hospital at Dala, Kano, $56 \mathrm{~km}$ from Dambatta. (This was the nearest radiography department capable of taking high quality chest radiographs.) Radiographic appearances were described according to the ILO U/C International Classification for Pneumoconiosis 1971. The radiographs were read independently by two of the authors who then discussed them jointly.

The quarries, pits, and caves in which the men had worked were visited while stonecutting was in progress. Pit dimensions were recorded and dust and rock samples were taken for analysis by the Department of Geology, ABU, Zaria and the Petrographical Department at the British Museum, London.

\section{RESULTS}

PREVALENCE OF SILICOSIS The diagnosis of silicosis in this group of 126 sandstone cutters was based entirely on the chest radiograph. The abnormalities, classified according to the ILO $\mathrm{U} / \mathrm{C}$ extended classification, are given in Table I. Seventy-seven men $(61 \%)$ had radiographs classified as $0 / 0$ and $0 / 1$ which were regarded as showing no evidence of pneumoconiosis. Fortynine $(39 \%)$ had radiographs classified as $1 / 0-3 / 3$ which were regarded as indicating pneumoconiosis.

Forty-three of the patients with silicosis had category 2 or 3 pneumoconiosis, and 17 had progressive massive fibrosis (PMF) representing $39 \%$ and $42 \%$ respectively of those with category
2 and category 3 pneumoconiosis; $77 \cdot 4 \%$ had sma opacities in five or six lung zones, and of the remainder $11(22.4 \%)$ had opacities in the lower two-thirds of the chest radiograph only, compare with five $(10.2 \%)$ in the upper two-thirds onl $\$$ Egg-shell calcification was seen in the hilar nodes of one man with category 1 silicosis.

PREVALENCE OF TUBERCUlosis Seven men hact radiographs suggestive of pulmonary tuberculosis All had silicosis, and acid-fast bacilli were ot served in the sputum of three. Acid-fast bacid were also found in the sputum of one man with PMF and in another man with category $2 \%$ type $\mathrm{r}$ pneumoconiosis in whom tuberculosis wås not suspected radiologically.

CIGARETTE SMOKING (Table III) Two men we smokers and one of them had silicosis. Two me were ex-smokers. All except the man with silicosis had chest symptoms.

COMPARISON OF MEN WITH AND WITHOUT SILICOSE Age (Table II) The patients with silicosis wero rather older than the rest. The maximum preq valence of silicosis and of PMF occurred in the 35-44 years age group.

Occupational history The men with silicosis ha worked in the quarries longer than the stonecutters with no evidence of silicosis. In 49 wit silicosis the mean total duration of work in the quarries was 22.8 (range 9-30) years compared to a mean of 9.8 (range 1-31) years for the 77 nom silicotics. The mean number of grindstones culf per day was 3.7 (range 2-7) for the silicotics and 3.0 (range 1-7) for the others. These differencés were significant at the $1 \%$ level.

The prevalence of silicosis rose from $6 \%$ is those exposed for less than 10 years to $80 \%$

T A B L E I I

AGE DISTRIBUTION OF 126 GRINDSTONE CUTTERS WITH AND WITHOUT SILICOSIS

\begin{tabular}{|c|c|c|c|c|c|c|}
\hline \multirow[b]{2}{*}{ Category } & \multicolumn{6}{|c|}{ Age (years) } \\
\hline & $15-24$ & $25-34$ & $35-44$ & $>44$ & Mean & Range \\
\hline $\begin{array}{l}0 \\
1 \\
2 \\
3\end{array}$ & $\begin{array}{r}13 \\
1 \\
0 \\
0\end{array}$ & $\begin{array}{r}36 \\
2 \\
6 \\
4\end{array}$ & $\begin{array}{r}20 \\
3 \\
18 \\
8\end{array}$ & $\begin{array}{l}8 \\
0 \\
7 \\
0\end{array}$ & $\begin{array}{l}30 \cdot 5 \\
34 \cdot 0 \\
39 \cdot 1 \\
33 \cdot 3\end{array}$ & $\begin{array}{l}15-60 \\
23-40 \\
25-65 \\
25-40\end{array}$ \\
\hline Total & 14 & 48 & 49 & 15 & $35 \cdot 1$ & $15-65$ \\
\hline $\begin{array}{l}\text { Silicosis } \\
\text { Prevalence \% }\end{array}$ & $7 \cdot 1$ & $\begin{array}{r}12 \\
25 \cdot 0\end{array}$ & $\begin{array}{r}29 \\
59 \cdot 2\end{array}$ & $\begin{array}{r}7 \\
46 \cdot 7\end{array}$ & $36 \cdot 0$ & $23-65$ \\
\hline $\begin{array}{l}\text { PMF } \\
\text { Prevalence } \%\end{array}$ & $\begin{array}{l}\mathbf{0} \\
\mathbf{0}\end{array}$ & $\begin{array}{r}3 \\
6 \cdot 3\end{array}$ & $\begin{array}{r}11 \\
22 \cdot 4\end{array}$ & $20 \cdot \frac{3}{0}$ & $38 \cdot 6$ & $25-65$ \\
\hline
\end{tabular}


those exposed for 20 years or more. No one who had worked for less than eight years in the pits had silicosis, and only one man who had worked for longer than 24 years did not have silicosis. Seven of the men with PMF had worked as cutters for only ten years. Four of these men were still active cutters and the other three had stopped cutting between six and ten years previously. Only eight of the men had worked in caves for one to six years; four of them had silicosis.

Fifty-one of the subjects had retired from stonecutting by the time of the survey. Half the 22 patients with silicosis who had given up stonecutting had done so because of respiratory symptoms whereas most of the other 29 had changed to another occupation for reasons other than symptoms.

Respiratory symptoms (Table III). Thirty-one $(63 \%)$ of the 49 men with silicosis had respiratory symptoms compared with $31(40 \%)$ of 77 men without silicosis, a significant difference $(P<0.02)$. In men without silicosis symptoms occurred in $35 \%$ of those who had worked for less than 10 years and in $50 \%$ of those who had worked for over 20 years. The commonest symptoms were breathlessness on moderate exertion (cycling or stonecutting) and chest pain. The earliest symptoms noticed by the patients with silicosis were cough $(42 \%)$, sputum $(19 \%)$, chest pain $(17 \%)$, breathlessness on moderate exertion $(11 \%)$, breathlessness on mild exertion $(8 \%)$, and breathlessness at rest $(3 \%)$. Three of the 17 men with PMF admitted to no symptoms.

Physical signs (Table III) Seventeen (35\%) of the 49 patients with silicosis had abnormal signs in the cardiorespiratory system and six $(8 \%)$ of the 77 stonecutters without silicosis also had signs $(P<0.01)$. Rales were the commonest sign. One of the men with silicosis had central cyanosis and advanced cor pulmonale. Eight of the men with PMF had no abnormal cardiorespiratory signs. Eight men had hand deformities attributable to an occupational traumatic osteoarthrosis. Abnormalities included destruction of the terminal phalanges, arthritis of the interphalangeal and metacarpophalangeal joints, and ulnar deviation at the wrist joint. Gross digital clubbing was seen in one man with silicosis and in another with no evidence of cardiorespiratory disease.

No eye injury was seen or reported to have been due to stonecutting.

Ventilatory capacity (Table IV) One hundred and twelve of the 126 subjects produced acceptable readings for $\mathrm{FEV}_{1}$ and $\mathrm{FVC}$. The remaining 14 were quite unable to perform the manoeuvre. $\mathrm{FEV}_{1} / \mathrm{FVC}^{\circ} \%$ is said to be independent of racial variation, although absolute values for $\mathrm{FEV}_{1}$ and FVC are smaller in Africans than in Europeans of the same age and size (Cotes, 1968). Predicted normal $\mathrm{FEV}_{1} / \mathrm{FVC} \%$ was calculated using the regression based on age of Berglund et al. (1963) (Table IV). Eight patients with silicosis and two of the stonecutters without radiographic evidence of the disease had ratios more than two standard deviations less than predicted. These men were regarded as having airways obstruction. Airways obstruction was significantly commoner in the patients with silicosis $(\mathrm{P}<0.02)$.

One hundred and twenty of the 126 subjects were able to produce acceptable readings for PEF. Predicted normal values based on age and height were calculated using the regression of Elebute and Femi-Pearse (1971), which was derived from a population of urban Nigerians in Lagos. These subjects are likely to have larger thoracic volume for their height than the relatively taller, slimmer Hausa stonecutters.

Seven of the patients with silicosis and three of the other stonecutters had PEF values more

T A B L E I I I

SYMPTOMS AND SIGNS IN 126 STONECUTTERS

\begin{tabular}{|c|c|c|c|c|c|}
\hline Symptom & $\begin{array}{l}\% \text { of } \\
49 \text { Men with } \\
\text { Silicosis }\end{array}$ & $\begin{array}{l}\% 7 \text { of } \\
\text { Men without } \\
\text { Silicosis }\end{array}$ & Sign & $\begin{array}{l}\% \text { of } \\
49 \text { Men with } \\
\text { Silicosis }\end{array}$ & $\begin{array}{l}\text { \% of of } \\
\text { Silicosis }\end{array}$ \\
\hline No respiratory symptoms & 37 & 60 & No cardiorespiratory signs & 65 & 92 \\
\hline $\begin{array}{l}\text { Breathlessness on moderate } \\
\text { exertion } \\
\text { Chest pain } \\
\text { Cough } \\
\text { Sputum }\end{array}$ & $\begin{array}{l}43 \\
43 \\
37 \\
33\end{array}$ & $\begin{array}{l}21 \\
29 \\
16 \\
16\end{array}$ & $\begin{array}{l}\text { Wheeze or crepitations } \\
\text { Right ventricular hypertrophy }\end{array}$ & $\begin{array}{l}24 \\
12\end{array}$ & $\begin{array}{l}4 \\
3\end{array}$ \\
\hline $\begin{array}{l}\text { Breathlessness on mild } \\
\text { exertion } \\
\text { Weight loss } \\
\text { Breathlessness at rest } \\
\text { Haemoptysis } \\
\text { Smoking } \\
\text { Ex-smoker }\end{array}$ & $\begin{array}{r}20 \\
12 \\
8 \\
2 \\
2 \\
0\end{array}$ & $\begin{array}{l}5 \\
8 \\
3 \\
5 \\
1 \\
3\end{array}$ & $\begin{array}{l}\text { Thoracic distortion } \\
\text { Cervical lymphadenopathy } \\
\text { Consolidation } \\
\text { Hand deformity } \\
\text { Digital clubbing } \\
\text { Hypertension }\end{array}$ & $\begin{array}{l}4 \\
4 \\
4 \\
4 \\
2 \\
2\end{array}$ & $\begin{array}{l}\mathbf{0} \\
\mathbf{0} \\
\mathbf{0} \\
\mathbf{8} \\
\mathbf{1} \\
\mathbf{0}\end{array}$ \\
\hline
\end{tabular}


T A B L E I V

VENTILATORY CAPACITY IN 126 STONECUTTERS RELATED TO RADIOGRAPHIC CLASSIFICATION

\begin{tabular}{|c|c|c|c|c|c|c|c|}
\hline & \multirow{2}{*}{\multicolumn{2}{|c|}{$\begin{array}{l}\text { No. of Standard Deviations } \\
\text { less than Predicted Normal }\end{array}$}} & \multicolumn{4}{|c|}{ Category of Pneumoconiosis } & \multirow[t]{2}{*}{ PMF } \\
\hline & & & 0 & 1 & 2 & 3 & \\
\hline FEV $_{1} /$ FVC $\%$ & $\begin{array}{l}>1 \\
>2 \\
>3 \\
>4\end{array}$ & $\begin{array}{l}<1 \\
<2 \\
<3 \\
<4\end{array}$ & $\begin{array}{r}54 \\
12 \\
2 \\
0 \\
0\end{array}$ & $\begin{array}{l}4 \\
0 \\
0 \\
0 \\
0\end{array}$ & $\begin{array}{r}14 \\
3 \\
0 \\
0 \\
0\end{array}$ & $\begin{array}{l}2 \\
2 \\
1 \\
1 \\
1\end{array}$ & $\begin{array}{l}9 \\
2 \\
2 \\
2 \\
1\end{array}$ \\
\hline $\begin{array}{l}\text { Total with airways obstruction as defined } \\
\text { Acceptable readings/failures }\end{array}$ & & & $\begin{array}{r}2 \\
68 / 9\end{array}$ & $\begin{array}{r}0 \\
4 / 2\end{array}$ & $\begin{array}{r}0 \\
17 / 2\end{array}$ & $\begin{array}{r}3 \\
7 / 0\end{array}$ & $\begin{array}{r}5 \\
16 / 1\end{array}$ \\
\hline PEF (1/min) & $\begin{array}{l}>1 \\
>2 \\
>3 \\
>4\end{array}$ & $\begin{array}{l}<1 \\
<2 \\
<3 \\
<4\end{array}$ & $\begin{array}{r}64 \\
10 \\
3 \\
0 \\
0\end{array}$ & $\begin{array}{l}0 \\
2 \\
0 \\
0 \\
0\end{array}$ & $\begin{array}{r}15 \\
3 \\
0 \\
0 \\
0\end{array}$ & $\begin{array}{l}4 \\
2 \\
0 \\
0 \\
1\end{array}$ & $\begin{array}{l}6 \\
4 \\
1 \\
3 \\
2\end{array}$ \\
\hline $\begin{array}{l}\text { Total with restrictive defect as defined } \\
\text { Acceptable readings/failures }\end{array}$ & & & $\begin{array}{r}3 \\
77 / 0\end{array}$ & $\begin{array}{r}0 \\
2 / 4\end{array}$ & $\begin{array}{r}0 \\
18 / 1\end{array}$ & $\begin{array}{r}0 \\
7 / 0\end{array}$ & $16 / 1$ \\
\hline
\end{tabular}

than two standard deviations less than predicted normal. Four of these ten men had normal $\mathrm{FEV}_{1} /$ FVC $\%$ and so were regarded as showing a purely restrictive type of ventilatory defect. There was no significant difference between the two groups of subjects.

All nine silicosis patients with abnormal ventilatory capacity had respiratory symptoms and seven had abnormal cardiorespiratory signs. Those with the most extensive radiographic changes had the most abnormal respiratory function.

On the other hand, ten patients with progressive massive fibrosis had ventilatory capacities that were either absolutely normal (four cases) or only mildly impaired (six cases) $\left(\mathrm{FEV}_{1} / \mathrm{FVC} \%\right.$ or PEF more than 1 SD but less than 2 SD below predicted normal), and three of these had neither symptoms nor abnormal physical signs. Although symptoms, signs, and airways obstruction were significantly commoner in men with silicosis, the correlation between these and radiographic abnormality was not very close.

Haematocrits The mean PCV in 49 patients with silicosis was $41.5 \%$ and in 72 subjects without silicosis was $40.2 \%$, an insignificant difference. Only two of the 121 stonecutters in whom PCV was measured had values below $35 \%$. This measurement was considered as a crude index of general nutritional state, systemic illness, and hookworm infection.

Rheumatoid factor (Table V) There were no significant differences in the presence of rheuma- 0 toid factor in low $(1: 20)$ or high $(1: 640)$ titrer between men with and without silicosis and normal Nigerian control values (Greenwood et al., 1971).

Description of rock samples The samples weræ of an impure sandstone containing larger detrita $B$ quartz crystals embedded in a hard matrix of kaolinite (clay) and microcrystalline quartz withB variable amounts of iron oxides. Quartz formed about $80 \%$ of the sample. Approximately one? third of the quartz was microcrystalline with a particle size less than one micron.

\section{DISCUSSION}

In this survey the diagnosis of silicosis was made radiographically. Illustrative examples of radio 3 graphs are shown in Figs 4, 5, and 6; there seems little doubt that such radiographic appearances? occurring in men employed quarrying sandston containing $80 \%$ quartz, represent silicosis. Although the lung biopsy taken from the indes case showed the histological appearances of indolent tuberculosis, this does not exclude్

T A B L E V

RHEUMATOID FACTOR IN THE SERA OF 126 STONECUTTERS AND IN NIGERIAN CONTROLS

\begin{tabular}{|c|c|c|c|c|c|c|c|}
\hline \multirow{2}{*}{ Titre } & \multicolumn{5}{|c|}{ Silicosis } & \multirow{2}{*}{$\begin{array}{c}\text { Normal } \\
\text { Radiograph }\end{array}$} & \multirow{2}{*}{$\begin{array}{l}\text { Nigerian } \\
\text { Controls }\end{array}$} \\
\hline & Simple & $\begin{array}{c}\text { Progressive } \\
\text { A }\end{array}$ & $\begin{array}{c}\text { Massive } \\
\text { B }\end{array}$ & $\begin{array}{c}\text { Fibrosis } \\
\mathrm{C}\end{array}$ & Total & & \\
\hline $\begin{array}{l}>1: 20 \\
>1: 640\end{array}$ & $\begin{array}{r}18 \\
7\end{array}$ & $\begin{array}{l}3 \\
0\end{array}$ & $\begin{array}{l}1 \\
2\end{array}$ & $\begin{array}{l}3 \\
0\end{array}$ & $\begin{array}{r}25(53 \cdot 2) \\
9(19 \cdot 1)\end{array}$ & $\begin{array}{r}35(50 \cdot 7) \\
6(8 \cdot 7)\end{array}$ & $\begin{array}{l}(64) \\
(18)\end{array}$ \\
\hline
\end{tabular}




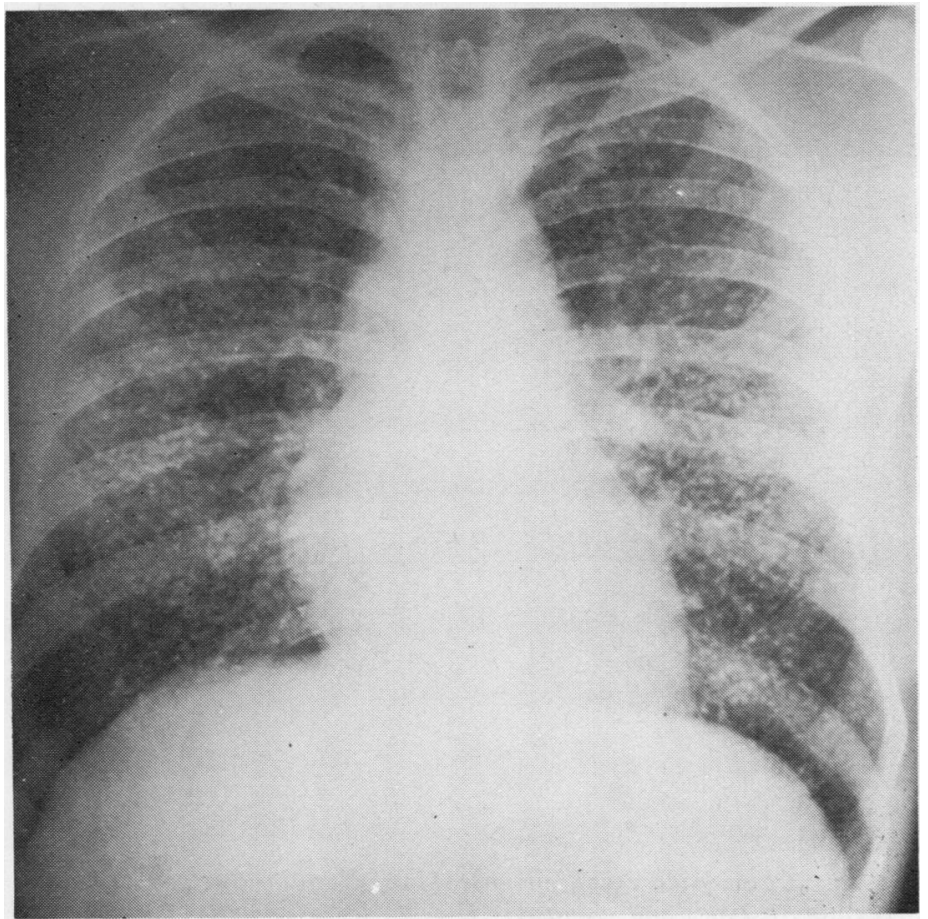

FIG. 4. Chest radiograph of case 1320. Calcified diffuse micronodular ( $q$ type) opacities in a man who had been stonecutting for 20 years.

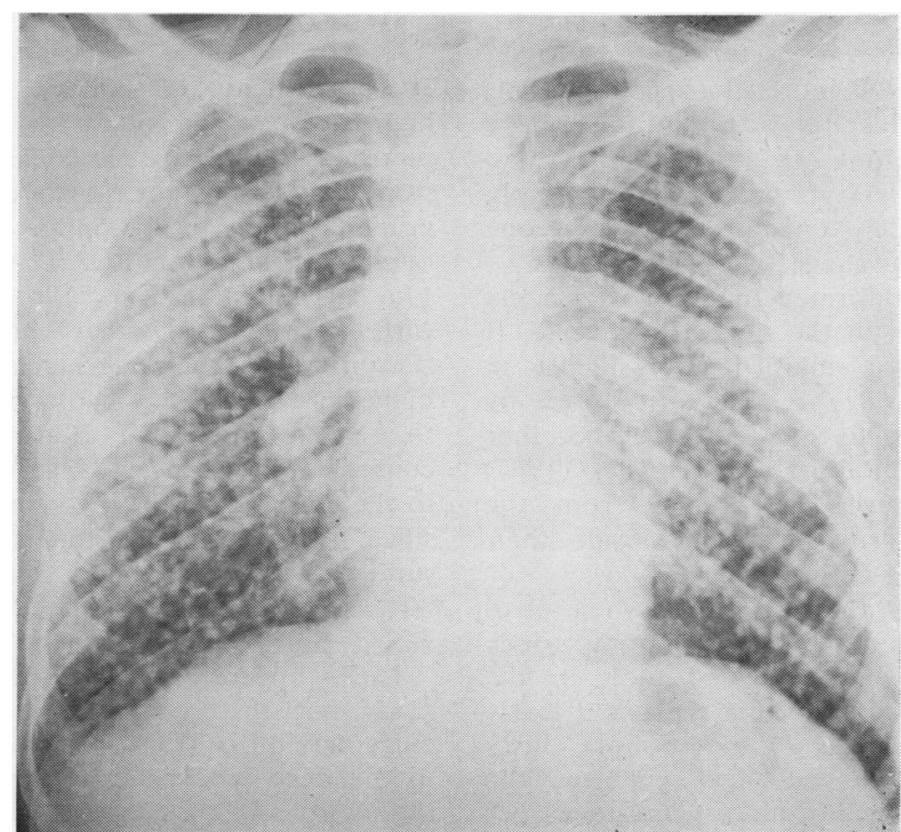

FIG. 5. Chest radiograph of case 1310. Diffuse nodular (r type) opacities with coalescence in a man who had been stonecutting for 20 years. 


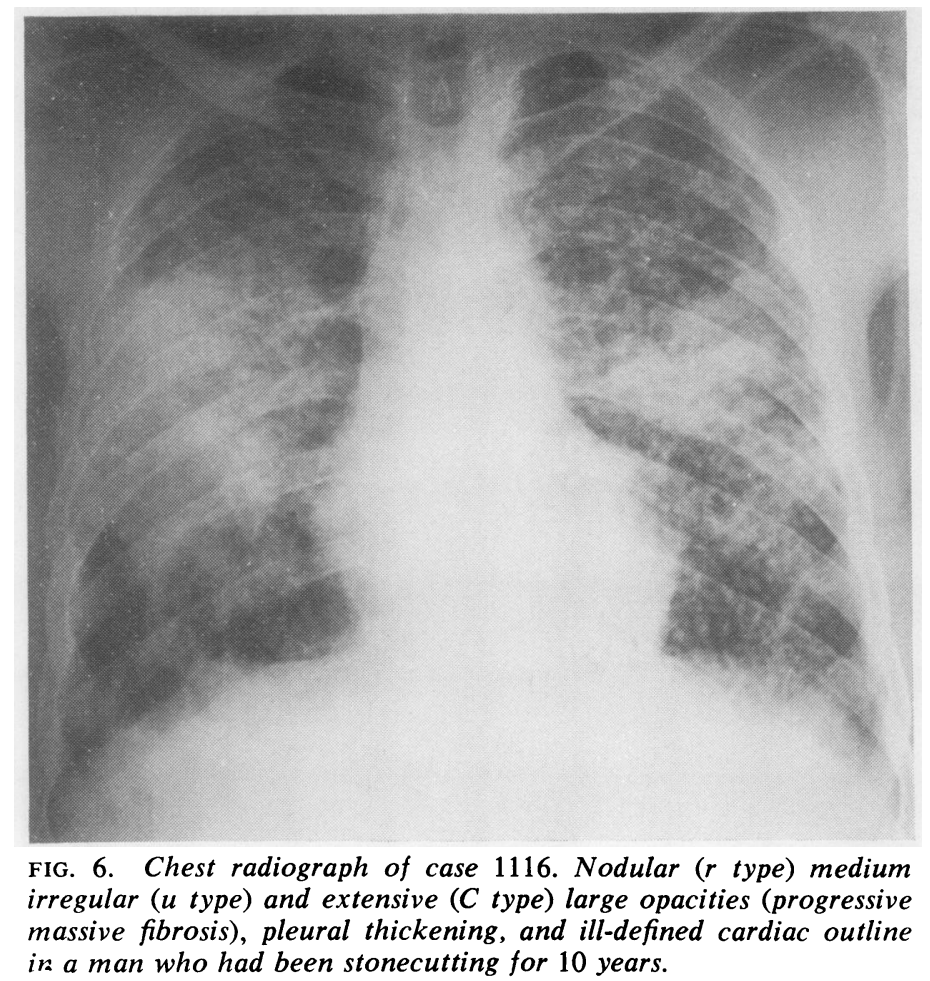

coexistent silicosis. Of more than 600 patients admitted to ABU Hospital with sputum-positive tuberculosis since June 1971, none has had micronodular opacities on the chest radiograph, whereas $39 \%$ of 126 stonecutters seen in one week had radiographs suggestive of silicosis.

This survey has confirmed that silicosis occurs in grindstone cutters in the north of Nigeria. It is the first report of a microfocus of silicosis in West Africa, and since it was discovered by chance it seems possible that there may be other foci in this region. Palmer and Daynes (1967) have described silicosis in women from the Transkei who use grinding stones inside their huts to produce flour from maize.

It is of interest that the stonecutters themselves have noticed respiratory symptoms only since the introduction of metal-headed tools in the second and third decades of this century. Clearly the occupation became very much more dusty as this technological advance enabled the quarriers to produce many more grindstones per year.

One hundred and eighteen men in this survey had worked exclusively in open pits, and the
$39 \%$ prevalence of silicosis seems exceptionally? high for open-cast quarrying. Gupta et al. (1972)? reported a similar prevalence $(35.2 \%)$ among stone masons in the north of India but radiographic surveys in Britain have shown lower rates, $x$ ranging from 3\% (Lloyd Davies et al., 1973) tog $17.6 \%$ (Hale and Sheers, 1963) in granite workers with a slightly higher prevalence of $19 \%$ (Ferguson,1934) among sandstone workers. The higher prevalence of silicosis in sandstone workers? than in granite workers is attributed to the higher content of free silica $(75-95 \%)$ in sandstone and to the composition of the cement which binds then silica. Analysis of the stone obtained during this survey showed that quartz formed approximatelyo $80 \%$ of the rock and that $20-30 \%$ of the rock was composed of fine-grained silica.

Dust concentration was not measured in thiso study but the occupation was observed to be् extremely dusty (Fig. 3). This was particularly so in the deep pits, and the dust generated by the initial process of hewing out the stone was in $\frac{0}{\mathbb{D}}$ creased by the habit of shaping and finishing the? stones in the shade of the pit rather than on the surface. This habit also increases the exposureo 
for each worker, and cutters reported that when work was in full swing it was impossible to see from one side of the pit to the other. Dust particle counts performed by Gupta et al. (1972) in India showed levels of between 15 and 51.5 million particles per cubic foot of air, far in excess of recommended levels for sandstone quarries. Environmental factors of extreme dryness and heat in this area of the Sudan savanna tend to increase the dust density. Gupta et al. (1972) considered that the high silica content of the stone coupled with the very high concentration of dust and the lack of any dust control measures were the major factors producing such a high prevalence of silicosis in their survey. Social factors which may contribute to the high prevalence of silicosis include the stoicism of rural underprivileged people (this was the first time in living memory that these villages had been visited by medical personnel) and the unrewarding nature of the major alternative occupation, which is farming, particularly during cycles of drought.

It is widely agreed that the early radiographic changes in silicosis are predominantly in the upper halves of the lung fields. This was not so in the present survey, and Gelfand and Morton (1970) in a survey of African gold miners in Rhodesia also found that the lower zones were involved as frequently as the upper zones in their patients.

Seven per cent of the samples of grindstone cutters had pulmonary tuberculosis, either suspected radiologically or proven by sputum microscopy. All had silicosis. This prevalence is the same as that found by Gupta et al. (1972); it is much higher than the estimated case prevalence in tropical Africa of $2 \%$ (Roelsgaard, Iversen, and Bløcher, 1964), but much lower than the figure of $34 \%$ among sandstone workers in Staffordshire who showed active pulmonary tuberculosis at necropsy (Meiklejohn, 1949).

Only one of the 126 men in this survey had cor pulmonale; he had PMF and pulmonary tuberculosis. Cor pulmonale was not reported by Gupta et al. (1972) in India, and Paul (1961) found few cases among copper miners with PMF in Zambia.

Rheumatoid factor $(1: 640)$ is found in $4-6 \%$ of British coal miners with simple pneumoconiosis (Caplan, Payne, and Withey, 1962; Soutar, Turner-Warwick, and Parkes, 1974). This is the same prevalence as in control populations. The same workers found a three-fold increase in the prevalence of rheumatoid factor in miners who had developed PMF. In Nigeria $18 \%$ of control rural populations have rheumatoid factor and the prevalence in the stonecutters with or without silicosis was not significantly different from this.

Prevention of silicosis in this drought-stricken area of Nigeria raises special problems. Stonecutting is more remunerative than farming, and the people in this place have been accustomed to stonecutting for so long that they are unlikely to change to farming, particularly in view of the recent drought.

Conventional dust control measures used in Europe and America are unrealistic in this environment; water shortage prevents dampingdown of the dust; it is too hot to wear respiratory masks and poverty precludes the use of more elaborate mechanical cutting tools.

The following recommendations were made to the stonecutters and village and district heads:

1. Abandon all caves and deep pits and excavate new shallow pits.

2. Avoid shaping and finishing the stones in the pits and erect simple shelters to provide shade so that this work can be done on the surface where there is natural ventilation.

3. Attempt to do most of the stonecutting during the rainy season or during windy weather.

The further possibilities which were discussed with the local government authorities were:

(a) the provision of state drilled wells to increase the supply of water;

(b) the hiring of mechanical cutters to the villagers by the state so that large masses of stone could be excavated and brought to the surface where the grindstones could be chipped out and finished under less dusty and better ventilated conditions.

This work was supported by the Wellcome Trust. We are grateful to Professor E. H. O. Parry for diagnosing the index case and for encouragement and help; to Dr. B. M. Greenwood for help with the rheumatoid factor; to the Chief Medical Officer of Kano State (Dr. A. Imam) for permission to carry out the survey; to the District Head, Divisional Officer, village heads, and hospital staff at Dambatta for their unreserved co-operation and help; to Professor A. W. Yakubowski, Dr. Gareth Williams, and Dr. George Simon for radiological help; to Dr. David Turner (Department of Geology, ABU, Zaria) and Mr. R. J. Merriman (Petrographical Department, British Museum) for expert opinions on the rock samples; and to Professor J. G. Scadding, Professor K. F. W. Hinson, and Professor Andrew Kertesz for reviewing the lung biopsy from the index case. 


\section{REFERENCES}

Berglund, E., Birath, G., Bjure, J., Grimby, G., Kjellmer, I., Sandqvist, L., and Söderholm, B. (1963). Spirometric studies in normal subjects. I. Forced expirograms in subjects between 7 and 70 years of age. Acta Medica Scandinavica, 173, 185.

Caplan, A., Payne, R. B., and Withey, J. L. (1962). A broader concept of Caplan's syndrome related to rheumatoid factors. Thorax, 17, 205.

Cotes, J. E. (1968). Lung Function, 2nd edition. Blackwell, Oxford.

Elebute, E. A. and Femi-Pearse, D. (1971). Peak flow rate in Nigeria. Thorax, 26, 597.

Ferguson, T. (1934). Silicosis among sandstone workers in Scotland and the North of England. Journal of Industrial Hygiene, 16, 203.

Gelfand, M. and Morton, S. A. (1970). Silicosis in the gold mining industry in Rhodesia. Central A frican Journal of Medicine, 16, 32.

Greenwood, B. M., Muller, A. S., and Valkenburg, H. A. (1971). Rheumatoid factor in Nigerian sera. Clinical and Experimental Immunology, 9, 161.

Gupta, S. P., Baja, A., Jain, A. L., and Vasudeva, Y. L. (1972). Clinical and radiological studies in silicosis: based on a study of the disease amongst stonecutters. Indian Journal of Medical Research, 60, 1309 .
Hale, L. W. and Sheers, G. (1963). Silicosis in West Country granite workers. British Journal of Industrial Medicine, 20, 218.

ILO U/C International Classification of Radiographs $\frac{\bar{D}}{\bar{N}}$ of Pneumoconiosis (1971). Occupational Safety and Health Series, International Labour Office, $\stackrel{\mathscr{Q}}{\varrho}$ Geneva.

Lloyd Davies, T. A., Doig, A. T., Fox, A. J., and Greenberg, M. (1973). A radiographic survey of. monumental masonry workers in Aberdeen. $\overrightarrow{\vec{H}}$ British Journal of Industrial Medicine, 30, 227.

Meiklejohn, A. (1949). Silicosis in sandstone workers. Some observations based on 275 necropsies. $\vec{x}$ British Journal of Industrial Medicine, 6, 241.

Palmer, P. E. S. and Daynes, G. (1967). Transkei silicosis. South African Medical Journal, 41, 1182. W

Paul, R. (1961). Silicosis in northern Rhodesia copper 6 miners. Archives of Environmental Health, 2, 96. 윽

Roelsgaard, E., Iversen, E., and Bløcher, C. (1964). Tuberculosis in Tropical Africa. Bulletin of the World Health Organisation, 30, 459.

Soutar, C. A., Turner-Warwick, M., and Parkes, W. R. $\stackrel{\text { क }}{\stackrel{5}{~}}$ (1974). Circulating antinuclear antibody and rheumatoid factor in coal pneumoconiosis. British $\vec{\theta}$ Medical Journal, 3, 145.

Requests for reprints to: Dr. D. A. Warrell, The Radcliffe Infirmary, Oxford OX2 6HE. 